\title{
Testing Rybczynski Theorem: An Evidence from The Selected European Transition Countries
}

\author{
Ljubo Jurcic, PhD \\ Teaching and Research Professor \\ Faculty of Economics and Business Zagreb, University of Zagreb \\ International Economics Department, J. F. Kennedy Square 6, 10000 Zagreb, Croatia \\ Email: ljurcic@efzg.hr, Phone: +38512383119 \\ Hrvoje Josic, PhD \\ Teaching and Research Assistant \\ Faculty of Economics and Business Zagreb, University of Zagreb \\ International Economics Department, J. F. Kennedy Square 6, 10000 Zagreb, Croatia \\ Email: hjosic@efzg.hr, Phone: +385992714483 \\ Mislav Josic, PhD \\ Teaching and Research Assistant \\ Faculty of Economics and Business Zagreb, University of Zagreb \\ International Economics Department, J. F. Kennedy Square 6, 10000 Zagreb, Croatia \\ Email: mjosic@efzg.hr, Phone: +385992714482
}

\section{Doi:10.5901/mjss.2013.v4n10p99}

\section{Abstract}

The goal of the paper is to test Rybczynski theorem in the case of selected European transition countries. Simple HeckscherOhlin model is extended in the analysis of many countries, two production factors and two products in the model. Assumptions of the theorem are conducted to scrutiny. The results of the analysis reject the hypothesis of the paper which states that "an increase in the endowment of one production factor, all other variables unchanged, will increase, by a greater proportion, the production of good that intensively uses that factor of production". There is an existence of cointegration between input-output changes only in case of Poland. There are few key reasons why Rybczynski theorem does not hold in European transition countries: human capital and land as other factors of production, unemployment, increasing marginal costs of production, trade barriers, differences in technology among countries, product diversification and other factors related to globalization and liberalisation of world trade.

Keywords: Factor endowment, Heckscher-Ohlin theory, Rybczynski theorem, transition European countries, cointegration, Johansen approach.

\section{Introduction}

Early theories of international trade which tried to explain why nations trade were Smith's theory of an absolute advantages and Ricardo's theory of comparative advantages created at the end of 18th and early 19th century. These theories observed international trade only from aspect of supply and neglected the aspect of demand respectively consumer behavior. Only factor of production was labor. Neoclassical view on international trade sources of comparative advantage no longer sees in different labor productivity among countries but in different relative endowments in two factors of production (labor and capital). Originators of the so called Heckscher-Ohlin model were Swedish economists Eli Heckscher and Bertil Ohlin in the early 1920's (Heckscher, E. (1919). The Heckscher-Ohlin (H-O) model of international trade is a general equilibrium model that predicts the pattern of trade and production based on the relative factor endowments in trading countries. It assumes two countries with constant returns to scale, identical homothetic preferences and technologies for two goods but different endowments for the two factors of production. The main prediction of the model is that each country will export the good that intensively uses their relatively abundant factor of 
production and import the good that intensively uses their scarce factor of production. There are four fundamental theorems in the Heckscher-Ohlin theory. They are Stolper-Samuelson theorem, Rybczynski theorem, Factor price equalization theorem and Heckscher-Ohlin theorem. All theorems are proved in the neoclassical framework under strong assumptions.

Well known Rybczynski theorem is one of most significant achievements in the international trade theory. Given a standard Heckscher-Ohlin framework the Rybczynski theorem states that "at given commodity price, if the endowment of some resource increases, the industry that uses that resource relatively intensively will increase its output, while the other industry reduces its output', Rybczynski (1955). Rybczynski investigated the effects of increase in the quantity of a factor of production upon production, consumption and terms of trade. In his analysis only one factor of production varied. The generalization of the theorem by Jones (1965) stated that "if factor endowments expand at different rates, the commodity intensive in the use of the fastest growing factor expands at a greater rate than either factor, and the other commodity grows (if at all) at a slower rate than either factor". The goal of this paper is to extend the analysis for the case of variations in quantities of two factors of production for many countries in the model using Jones's concept. The paper is structured in a way that in second chapter gives an overview of the scientific literature on Rybczynski theorem. In third chapter theoretical proposition of Rybczynski theorem is carried out. The fourth chapter tests Rybczynski theorem in the case of selected European transition countries. In conclusion of the paper is presented contribution of the analysis and concluding remarks.

\section{Economic Literature On The Rybczynski Theorem}

The Rybczynski theorem along with the Stolper-Samuelson, Factor-price equalization and Heckscher-Ohlin theorem is one of four key propositions describing the properties of the standard Heckscher-Ohlin model with two goods and two factors. The Polish-born economist Tadeusz M. Rybczynski ${ }^{1}$ (1923-1998) in his famous paper "Factor Endowment and Relative Commodity Prices" (1955) related changes in an economy's factor supplies to resulting changes in equilibrium output and prices. Rybczynski's proof makes use of the Edgeworth box diagram as applied for the first time to production by Wolfgang Stolper and Paul A. Samuelson in their landmark paper, "Protection and Real Wages" (1941), which presented what is now known as the Stolper-Samuelson theorem. Rybczynski builds on Stolper and Samuelson's key insight of the Heckscher-Ohlin model which stated that the relative price of the two goods uniquely determines factor prices and thus factor proportions. Below is an overview of economists that have contributed to the development of theory regarding Rybczynski theorem.

The Rybczynski theorem was originally derived for the case of production function which were assumed to be linearly homogeneous. Jones (1956) however investigated variable returns to scale using various methods to derive necessary and sufficient conditions for the theorem to this case as well. In his 1965 paper "The Structure of Simple General Equilibrium Models" Ronald Jones gives alternative formulations of the Rybczynski theorem which offers the first integrated treatment, as well as a number of generalizations, of the four key theorems of the Heckscher-Ohlin model. Hanson and Slaughter (1999) examined whether immigration altered U.S. regional output mixes as predicted by the Rybczynki Theorem. They pointed out two main findings: first, state output-mix changes broadly match state endownment changes and second that variation in state unit factor requirements is consistent with relative factor-priceequalisation across states. Wong (2000) examined the validity of the fundamentals theorems in the positive theory of international trade in a basic model of external economies of scale. The result of the analysis showed that if global changes under the specified adjustment mechanism are allowed, the Rybczynski and Stolper-Samuelson theorems are always valid, whether or not the production equilibrium is stable. Chakrabarti (2001) demonstrated the implications of asymmetric adjustment costs for the Rybczynski theorem and shows it can be sensitive to the existence of asymmetry in adjustment costs. The Rybczynski path is shown to be a special case of a more general expansion path. Pfingsten and Wolff (2006) discussed about the validity of Rybczynski's theorem under increasing marginal costs within firms or industries. They assumed that economy is exposed to increasing marginal costs, and thus to diseconomies of scale, within each industry. This assumption was motivated by a critical assessment of the standard replication argument for constant returns, both from a theoretical and an empirical perspective. They showed that an extra supply of any factor may lead to an expansion of all sector outputs if at least one sector permits input substitution. Opp et al (2009) demonstrated that an increase in endowment of a factor of production can lead to an absolute curtailment in the production of the commodity using that factor intensively, and an absolute expansion of the commodity using relatively

1 Tadeusz Rybczynski (1923-1998) was a Polish-born English economist. He studied at the London School of Economics. Immediately after discovering his famous theorem, he joined Lazard and spent the rest of his career there as an investment banker. 
little of the same factor. This outcome which is called "Reverse Rybczynski" implies immiserizing factor growth. Jošić, $\mathrm{H}$ and Jošić, M. (2011) investigated the duality relationship between Stolper-Samuelson and Rybczynski theorem. Using the unit-value isocosts and unit-value isoquants and their basic properties lead to new findings regarding the two aforementioned theorems where prices of final goods are given endogenously.

\section{Theoretical Aspects Of The Rybczynski Theorem}

In this chapter are given theoretical aspects of the Rybczynski theorem by explaining the key assumptions of the theorem using Edgeworth box diagram.

Let us assume the simplest version of the Heckscher-Ohlin model with two countries; country $A$ and country $B$ , two products (say agricultural and industrial product) produced using the same two factor inputs, labor and capital which are fully employed in production, but in proportions that differ across the two industries. Country $A$ is relative labor abundant and country $B$ is relative capital abundant. There are constant returns in the production of each individual factor. Specialization in production is incomplete which means that each country produces each product but in different amount. There is a free trade without restrictions and no transportation costs. Preferences of consumers in both countries are identical like technology which is assumed to be the same. Agricultural product uses a higher ratio of labor to capital, it is termed the labor-intensive product, while the industrial product is termed capital-intensive product.

At a given percentage increase in the supply of one factor, say labor, holding constant the supply of the second factor (capital) as well as the relative price of the two products, must result in a still larger percentage increase in the equilibrium output of the product that is labor-intensive in production (agricultural product), and an absolute decrease in the equilibrium output of the product that is capital-intensive (industrial product). Edgeworth box diagram for the case of increase in the labor force is presented in the figure 1.

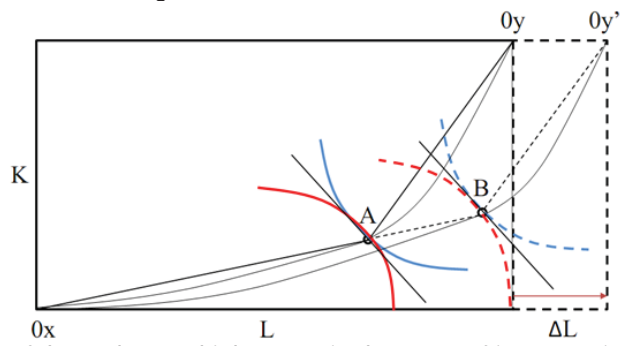

Figure 1: Edgeworth box diagram of the Rybczynski theorem in the case of increase in the labor force.

Edgeworth box diagram allows a convenient demonstration of the reason why an increase in a country's factor endowment will cause the output of one product to rise and the other product to fall. From the assumptions of the theorem we can say it is production function of country $A$ because it has relatively more labor than capital. Agricultural product is presented with $X$ and industrial product is presented with $Y$. The contract curve is convex with equilibrium in point $A$ where the isoquants of agricultural and industrial product are tangent. The position on the curve is determined by the condition which states that the substitution rate in production between product $X$ and product $Y$ must be equal to the substitution rate in consumption. Suppose this condition is fulfilled at the point $A$. Increase in quantity of labor force is presented with $\Delta L$. An increase in labor force will result in a greater increase in agricultural production, so called magnification effect identified by Ronald Jones. Not only is the all labor in the economy allocated to the agricultural production but additional labor and capital are released by the contraction of industrial production necessary to maintain labor/capital ratio in the agricultural production. The percentage of increase of the agricultural production is greater than the percentage increase in the labor force. The new equilibrium point is now $B$ where the isoquants of two products are tangent.

\section{Empirical Analysis Of Rybczynski Theorem In The Case Of Selected European Transition Countries}

The goal of this chapter is to empirically test Rybczynski theorem in the case of selected European transition countries. Difference from the original Rybczynski paper is that analysis is extended to variation in quantities of two factors of 
production (labor and capital) and not only in one factor of production. Data for analysis were collected from the EUROSTAT and EBRD.

Table 1: Input-output changes in selected European transition countries (total \% change)

\begin{tabular}{|l|c|c|c|c|c|}
\hline Country & Year & Capital & Labor force & $\begin{array}{c}\text { Agricultural } \\
\text { gross output }\end{array}$ & $\begin{array}{c}\text { Industrial } \\
\text { gross output }\end{array}$ \\
\hline Bulgaria & $1993-2009$ & 182,3 & $-11,9$ & 4,5 & $-1,4$ \\
Czech Republic & $1993-2009$ & 488,8 & 3,1 & $-14,4$ & 67,7 \\
Latvia & $1996-2009$ & 164,9 & $-9,7$ & 35,6 & 55,6 \\
Lithuania & $1996-2009$ & 114,1 & $-18,3$ & 23,5 & 65,6 \\
Poland & $1993-2009$ & 131,3 & 1,6 & 18,2 & 103,9 \\
Russian Federation & $1995-2009$ & 56,1 & 1,6 & 21,5 & 42,6 \\
Slovakia & $1993-2009$ & 74,9 & 9,5 & $-49,4$ & 61,6 \\
Slovenia & $1993-2009$ & 124,1 & 16,6 & 5,9 & 43,6 \\
Ukraine & $1995-2009$ & 84,3 & $-26,9$ & 12,5 & 62,0 \\
\hline
\end{tabular}

Source: EUROSTAT, EBRD and authors calculations

In table 1 are shown input-output changes between factors of production and production of agricultural and industrial output in selected European transition countries. Countries included in analysis are Bulgaria, Czech Republic, Latvia, Lithuania, Poland, Russian Federation, Slovakia, Slovenia and Ukraine. Analysis is conducted for the period between 1993 and 2009. Other transitional countries were not included into the analysis because data were available only for shorter time periods. Variables of interest are gross fixed capital formation $(C A P)^{2}$, labor force $(L A B)$, agricultural gross output $(A G O)$ and industrial gross output $(I G O)$. Data are aggregated as total cumulative of percentage change for the observed period. According to Rybczynski theorem if quantity of one production factor increases relatively more than the other factor of production, the production of product that relatively intensively uses that factor of production should also increase relatively more than production of other product.

In accordance with the Rybczynski theorem the hypothesis of the paper states:

$\mathrm{H}_{1} \ldots$.. "An increase in an endowment of one production factor, all other variables unchanged, will increase, by a greater proportion, the output of the product using intensive changing factor of production and decrease, by a smaller proportion, the output of the product relatively intensive in other factor."

In order to empirically test the hypothesis of the paper we use linear regression econometric analysis, unit root testing and Johansen approach for cointegration testing. The first step in the analysis is to calculate and compare differences between changes in capital and labor force endowments $(C A P-L A B)$ as well as industrial gross output and agricultural gross output changes $(I G O-A G O)$ for the selected countries. The data are presented as cumulative percentage change in the observed period. Before using Johansen approach for cointegration testing between factor and output changes we need to examine the time data stationarity. Testing for the order of integration is standard in applied econometrics. There are two motives behind unit root tests. The first is knowing that the order of integration is crucial for setting up an econometric model and do inference. The second motive is that economic theory suggests that certain variables should be integrated, a random walk or a martingale process (Sjö (2008)). If variables in the regression model are not stationary then it can be proved that the standard assumptions of the model will not be valid. In that case spurious regression can arise as a problem. Only in situation where the variables are the same order of integration, the cointegration analysis can be performed.

In table 2 are presented results of the stationarity testing on the derived variables $(I G O-A G O)$ and $(C A P-L A B)$ using Augmented Dickey-Fuller (ADF) unit root test ${ }^{3}$ (Dickey, D. A. and Fuller, W. A. (1979)). The results of the analysis has shown that the derived variables $(I G O-A G O)$ and $(C A P-L A B)$ are of second order

${ }^{2}$ Gross fixed capital formation refers to the net increase in physical assets (investment minus disposals) within the measurement period. It is a component of expenditure approach to calculating GDP, does not account for the consumption (depreciation) of fixed capital, and also does not include land purchases.

${ }^{3} \mathrm{ADF}$ test is a basic test for the order of integration. It can be set in three ways, depending on what we want the alternative hypothesis to be. In our case we use constant and trend. The null hypothesis of a unit root is rejected in favour of the stationary alternative in each case if the test statistic is more negative than the critical value. 
of integration under the significance of $1 \%, 5 \%$ and $10 \%{ }^{4}$ These time data series needs to be differentiated two times to be stationary. ${ }^{5}$ Critical values are calculated for the 20 observations and may not be accurate for the sample size less than 20.

Table 2: Results of stationarity and cointegration testing using Johansen procedure on the variables industrial gross output minus agricultural gross output $(I G O-A G O)$ and capital minus labor force $(C A P-L A B)$ for selected European transition countries

\begin{tabular}{|c|c|c|c|c|c|c|c|c|}
\hline Country & Year & $\begin{array}{c}\text { Stationarity } \\
(I G O-A G O)\end{array}$ & $\begin{array}{c}\text { Stationarity } \\
(C A P-L A B)\end{array}$ & $\begin{array}{c}\text { Trace } \\
\text { Statistic }\end{array}$ & Prob. & \begin{tabular}{c|} 
Max- \\
Eigen \\
Statistic \\
\end{tabular} & Prob. & Cointegration \\
\hline Bulgaria & $1993-2009$ & $-6,95, \mathrm{I}(2) *$ & $-4,60, \mathrm{I}(2) *$ & 7,57 & 0,51 & 6,78 & 0,51 & NO \\
\hline Czech Republic & $1993-2009$ & $-5,91, \mathrm{I}(2)^{8}$ & $-4,38, I(2)^{*}$ & 16,82 & 0,03 & 13,54 & 0,06 & No \\
\hline Latvia & $1996-2009$ & $-3,62, \mathrm{I}(2)^{* *}$ & $-3,74, \mathrm{I}(2) * *$ & 16,59 & 0,03 & 11,68 & 0,12 & No \\
\hline Lithuania & $1996-2009$ & $-5,53, \mathrm{I}(2) *$ & $-3,57, \mathrm{I}(2) * *$ & 14,27 & 0,07 & 13,62 & 0,06 & No \\
\hline Poland & $1993-2009$ & $-4,28, \mathrm{I}(2)^{*}$ & $-3,61, I(2)^{* *}$ & 18,89 & 0,01 & 18,89 & 0,01 & YES \\
\hline $\begin{array}{l}\text { Russian } \\
\text { Federation }\end{array}$ & $1995-2009$ & $-3,67, \mathrm{I}(2) * *$ & $-4,93, \mathrm{I}(2)^{*}$ & 9,77 & 0,29 & 7,55 & 0,42 & NO \\
\hline Slovakia & $1993-2009$ & $-7,23, \mathrm{I}(2)^{*}$ & $-3,68, I(2) * *$ & 14,44 & 0,07 & 12,88 & 0,08 & No \\
\hline Slovenia & $1993-2009$ & $-3,71, \mathrm{I}(2)^{* 8}$ & $-3,04, I(2)^{8}$ & 15,46 & 0,05 & 13,00 & 0,08 & NO \\
\hline Ukraine & $1995-2009$ & $-6,41, \mathrm{I}(2)^{*}$ & $-4,78, I(2)^{8}$ & 7,49 & 0,52 & 6,53 & 0,54 & No \\
\hline
\end{tabular}

Note: Number of lags in the model was determined by minimizing Schwarz information criterion, * indicate significance under $1 \%$, ** indicate significance under 5\%, *** indicate significance under 10\%, 0,05 Critical Value for Unrestricted Cointegration Rank Test (Trace) is 15,49 and 0,05 Critical Value for Unrestricted Cointegration Rank Test (Maximum Eigenvalue) is 14,26

\section{Source: Authors calculations}

After determining the order of integration the next step in analysis is to relate changes in production factors to changes in output of production. For that purpose we use Johansen cointegration approach ${ }^{6}$ (Johansen, S. (1988), Johansen, S. and Juselius, K. (1990), Johansen, S. (1995)). Cointegration is a statistical property of time series variables. It can be said that two or more time series are cointegrated if they share a common stochastic drift. It can have higher order of integration (I(1), I(2)) but some linear combination still can have a lower order of integration and be cointegrated. In practice, cointegration is often used for two I(1) series, but it is more generally applicable and can be used for variables integrated of higher order (to detect correlated accelerations or other second-difference effects). A common example is where the individual series are first-order integrated (I(1)) but some (cointegrating) vector of coefficients exists to form a stationary linear combination of them. Before using Johansen cointegration test variables are transformed into I(1) using first differences. In Johansen's test procedure there are two test statistics: the trace statistics and the maximum eigenvalue statistic. The trace statistic tests the null hypothesis: "there are at most $r$ cointegrating relations" against the alternative of " $m$ cointegration relations" (i.e., the series are stationary), $r=0,1, \ldots, m-1$. On the other hand, the maximum eigenvalue statistic test the null hypothesis:"there are $r$ cointegrating relations" against the alternative:"there are $r+1$ cointegrating relations". In applications of Johansen's method it can happen that trace statistic and maximum eigenvalue statistic gave different results like in our case where critical values are calculated for the 20 observations and may not be accurate for the sample size less than 20 .

\footnotetext{
4 The majority of econmic and financial series contain a single unit root, although some are stationary and consumer prices have been argued to have 2 unit roots.

${ }^{5}$ The reason why the series are I(2) becuse we use cumulative values for the observed period.

6 Johansen test of cointegration is one of the mostly used in practice when testing for cointegration. The weakness of the test is that it relies on asymptotic properties and is sensitive to specification errors in limited samples.
} 

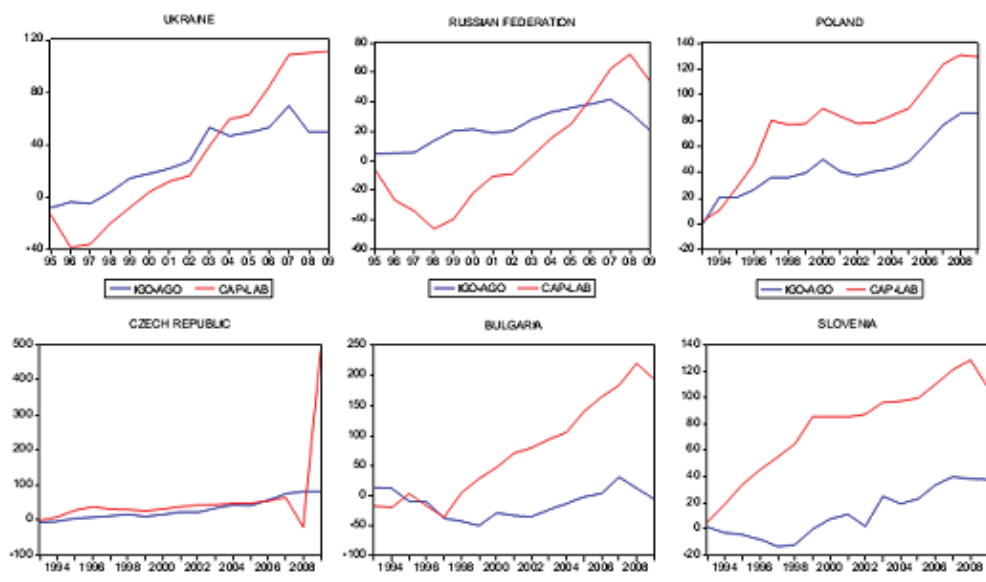
$-100000-\mathrm{COON}$ 国

Butgen

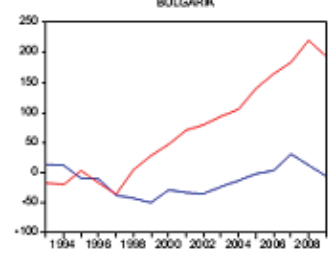

$-100400-00240$

SLOVENm

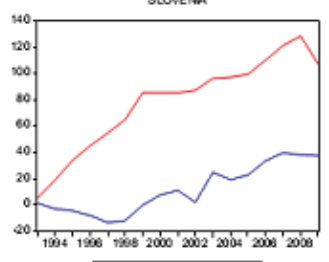

- $\mathrm{COACO}$ - CAPUAB

sovmKn

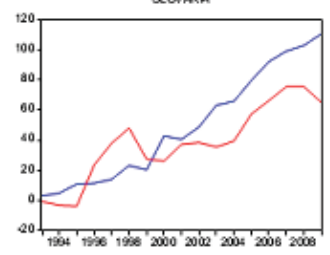

- COANOS - CAPLAB

unewn

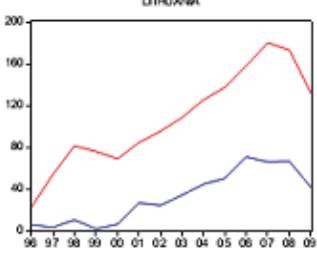

-KONGO - CAPUB

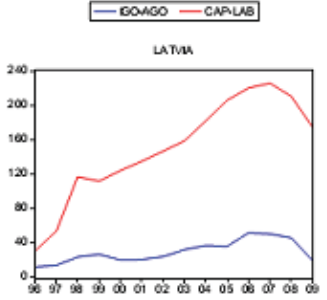

- canso-chave

Figure 2: Cointegration between output changes $(I G O-A G O)$ and factor changes $(C A P-L A B)$ for selected European transition countries

Obtained contradiction may be attributed to the lower power of cointegration tests resulting from the small number of available observations (Bahovec, V., Erjavec (2009)). Trace statistic has shown the existence of cointegration vector in case of Czech Republic, Latvia and Poland (trace statistic values are higher than $5 \%$ critical value which amounts at 15,49). On the other hand, maximum eigenvalue statistic has shown the existence of cointegration vector only in case of Poland (Max-Eigen statistic higher than 5\% critical value which amounts at 14,26). For the testing of the existence of cointegration we also used graphical method. From the figure 2 it can be seen the existence of cointegration only in case of Poland while time data series in Latvia slightly diverge one from another in observed period and in case of Czech Republic there is an evident structural break in the year 2008 and 2009.

It can be concluded that Rybczynski theorem do not hold in its original form in the case of European transition countries except in the case of Poland.7 In order to correctly explain the results of the analysis we need to review the assumptions of the model. Rybczynski theorem lies on many assumptions which addresses complexity of the model. Each model is as complex as there are assumptions that restricts it. At briefly look it can be seen that many of the assumptions of the Rybczynski theorem do not hold. Except labor and capital as main production factors there are land and human capital as other factors of production which were not included in analysis. Unemployment is also the vital question when testing Rybczynski theorem. Heckscher-Ohlin theory excludes unemployment by the very formulation of the model, in which all factors (including labour) are employed in the production. But the unemployment is important factor in global economy. Other reasons why the Rybczynski theorem do not hold in practice are increasing and decreasing marginal costs of production (not only constant returns to scale), various barriers to free trade (customs, quoatas, quantitive restrisctions), differences in technology of production in countries, product diversification and other factors related to globalization and liberalisation of world trade. It can be concluded that the Rybczynski theorem do not hold in its original form in European transition countries. The reason is primarily because it is restricted with so many assumptions which do not hold in liberalized and globalised economy. It can be also stated that it do not generally hold in the international trade because in the last half a century there has been significant changes in global economy and

\footnotetext{
${ }^{7}$ Which is a quite symbolic because the originator of Rybczynski theorem Tadeusz Rybczynski was Polish born economist.
} 
trade patterns. But the Rybyczynski theorem stays as one of the most famous theorems in international trade widely accepted by its simplicity and clarity.

\section{Conclusion}

The Rybczynski theorem along with the Stolper-Samuelson, Factor-price equalization and Heckscher-Ohlin theorem is one of four key propositions describing the properties of the standard Heckscher-Ohlin model with two goods and two factors. Many authors have contributed to the development of a theory related to Rybczynski theorem. Our analysis started by explaining the key assumptions of the theorem using Edgeworth box diagram. In the final chapter of the paper Rybczynski theorem was empirically tested in the case of selected European transition countries. Difference from the original Rybczynski paper (1955) was that analysis is extended to variations in quantities of two factors of production (labor and capital).

Variables of interest were gross fixed capital formation, labor force, agricultural gross output and industrial gross output. Data were aggregated as total cumulative of percentage change for the observed period. Next step in the analysis was to relate changes in quantities of production factors of and changes in output of two production sectors. The hypothesis of the paper, which we wanted to prove, stated that "an increase in endowment of one factor of production compared to another factor will increase the output of the product relatively intensive in that factor" as original Rybczynski said.

But the results of the analysis has shown otherwise: there is no or little correlation between difference in factor endowments and output production except in the case of Poland. It can be concluded that the Rybczynski theorem do not hold in its original form in European transition countries. Key reasons why Rybczynski theorem do not hold in practice were violated key assumptions of the model; human capital and land as other major factors of production, unemployment, increasing marginal costs of production, barriers to free trade, differences in technology of production, product diversification and other factors related to globalization and liberalisation of world trade. But the Rybyczynski theorem stays as one of the famous theorems in international trade widely accepted by its simplicity and clarity.

\section{References}

Bahovec, V., Erjavec, N. (2009) „Uvod u ekonometrijsku analizu“, 1. izdanje, Element, ožujak 2009.

Bo Sjö (2008) „Testing for Unit Roots and Cointegration“. Available at: http://www.iei.liu.se/nek/ekonometrisk-teori-7-5-hp730a07/labbar/1.233753/dfdistab7b.pdf

Chakrabarti (2001) „Rybczynski theorem and asymmetric adjustment costs“, KEIO Economic studies 38(1), 33-41 (2001).

Dickey, D. A. and Fuller, W. A. (1979) Distribution of the Estimators for Autoregressive Time Series With a Unit Root, Journal of the American Statistical Association, 74, 427-431.

Hanson, G.H., Slaughter, J.M. (1999) „The Rybczynski Theorem, Factor-Price Equalization, and Immigration: Evidence from U.S.States", Discussion Paper No. 448.

Heckscher, E. (1919) „The effect of foreign trade on the distribution of income", Ekonomisk Tidskriff, 497-512.

Jones, R. (1956) „Factor proportions and the Heckscher-Ohlin theorem", Review of Economic Studies, 24, 1-10.

Jones, R. (1965) "The Structure of Simple General Equilibrium Models“, The Journal of Political Economy, Vol.73, No.6 (Dec.1965), $557-572$.

Johansen, S. (1988) „Statistical Analysis of Cointegrating Vectors“, Journal of Economic Dynamics and Control, 12: 231-254.

Johansen, S. (1995) „Likelihood-based inference in cointegrated vector auto-regressive models“, Oxford: Oxford University Press.

Johansen, S. and Juselius, K. (1990) „Maximum Likelihood Estimation and Inference on Cointegration with Application to the Demand for Money", Oxford Bulletin of Economics and Statistics, (52): 169-209.

Jošić H., Jošić, M. (2011) „An impact of relative factor price changes on the structure of production,“Proceedings oft he FEB, Vol.9, nbr.2. 2011.

Opp, M.M., Sonnenschein F.H., Tombazos G.C. (2009) „Rybczynski's Theorem in the Heckscher-Ohlin World - Anything Goes“, Journal of International Economics, 79 (2009) 137-142.

Pfingsten, A., Wolff. R. (2006) "Local Factor Supply Changes in Small Open Economies: Rybczynski Derivatives under Increasing Marginal Costs", Conference on "Small Open Economies in a Globalized World, University of Bologna 2006.

Rybczynski, T.M. (1955) "Factor endowments and relative commodity prices", Economica 22, 336-41.

Stolper W. F., Samuelson, P. A. (1941) "Protection and Real Wages", The Review of Economic Studies, Vol. 9, No. 1 (Nov., 1941), pp.

Wong, K. (2000) „Fundamental Trade Theorems under External Economies of Scale“, Available at: http://faculty.washington.edu /karyiu/papers/ext-eos.pdf. 